\title{
Video-assisted thoracoscopic surgery is a safe and effective method to treat intrathoracic unicentric Castleman's disease
}

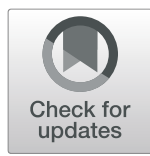

Yan-qing Wang, Shan-qing Li and Feng Guo*

\begin{abstract}
Background: Castleman's disease (CD) is a rare non-clonal lymphadenopathy. Application of video-assisted thoracoscopic surgery (VATs) in intrathoracic unicentric Castleman's disease (UCD) is rarely reported. This study is aimed to clarify the role of VATs for diagnosis and treatment in intrathoracic UCD.

Methods: The authors reviewed and identified patients who had received a histologic diagnosis of CD through VATs at our hospital from January2010 to June 2018. Clinical and radiologic variables, histopathology, type of approach, complications, and long-term effect were analyzed to evaluate the safety and efficacy of VATs.

Results: A total of 10 patients were included in this study, with 8 hyaline vascular type and 2 plasma cell type. The mean maximum diameter of the lesions was $4.66 \mathrm{~cm}$. Nine cases underwent complete surgical excision by VATs, and 1 case was converted to thoracotomy. All patients had no postoperative complications. With a median followup of 5 years (range: 1-9 years), no tumor recurrence was found in 9 patients receiving complete tumor resection, and 1 patient with incomplete tumor resection remained symptom free without clinical or radiographic progression.
\end{abstract}

Conclusions: VATs is an alternative, minimally invasive technique for the diagnosis and treatment in patients with intrathoracic UCD.

Keywords: Castleman's disease, Video-assisted thoracoscopic surgery, Treatment

\section{Background}

Castleman's disease (CD) is a rare non-clonal lymphadenopathy that was first named in 1956 by Castleman et al. [1, 2] Three histopathologic subtypes have been identified, including hyaline vascular, plasma cell, as well as mixed variant [3]. Castleman's disease can be divided into unicentric type (UCD) and multicentric type (MCD) on the basis of the distribution of enlarged lymph nodes and organ involvement. Hyaline vascular type is more common in UCD but rare in MCD. The vast majority of $U C D$ is mainly located in the chest, and

\footnotetext{
* Correspondence: guofeng@pumch.cn
Department of Thoracic Surgery, Peking Union Medical College Hospital,

* Correspondence: guofeng@pumch.cn
Department of Thoracic Surgery, Peking Union Medical College Hospital, Chinese Academy of Medical Sciences \& Peking Union Medical College, 100730No 1 ShuaiFuYuan Street, Dong Cheng District, Beijing, People's Republic of China
}

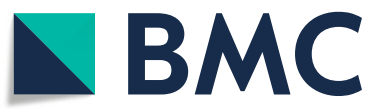

(c) The Author(s). 2020 Open Access This article is licensed under a Creative Commons Attribution 4.0 International License, which permits use, sharing, adaptation, distribution and reproduction in any medium or format, as long as you give appropriate credit to the original author(s) and the source, provide a link to the Creative Commons licence, and indicate if changes were made. The images or other third party material in this article are included in the article's Creative Commons licence, unless indicated otherwise in a credit line to the material. If material is not included in the article's Creative Commons licence and your intended use is not permitted by statutory regulation or exceeds the permitted use, you will need to obtain permission directly from the copyright holder. To view a copy of this licence, visit http://creativecommons.org/licenses/by/4.0/ The Creative Commons Public Domain Dedication waiver (http://creativecommons.org/publicdomain/zero/1.0/) applies to the data made available in this article, unless otherwise stated in a credit line to the data.

can occur in posterior mediastinal [4], cardiophrenic angle [5], and chest wall [6]. Due to the lack of specificity of enhanced computed tomography, CD was often misdiagnosed as thymoma, lymphoma, hemangiopericytoma, sarcoma, chest wall tumors, neural crest derived neoplasms, bronchial tumor, or pericardial cyst [3, 7]. The diagnosis of Castleman's disease can only be made by histopathological confirmation.

Surgery plays a critical role in the diagnosis and management of $\mathrm{CD}$ since it provides tissue-based diagnosis and greatest chance for cure [8]. It has been considered as the standard therapy for UCD, which was usually performed via conventional thoracotomy $[9,10]$. At present, video-assisted thoracoscopic surgery (VATs) is becoming increasingly popular in the thoracic area, which had 
been proven to be a safe and effective treatment for many thoracic diseases, including mediastinal masses, lung cancer, and pleural diseases [11, 12]. Compared with traditional thoracotomy, VATs provides safer, less invasive resection with shortened hospital stays and faster recovery [13]. However, as far as we know, limited evidence is available about the application VATs in UCD with few studies reporting long-term effects [14-17].

Therefore, here we presented a retrospective analysis by reviewing the $\mathrm{CD}$ cases which were diagnosed and treated by VATs in our institution to investigate the role of VATs for the diagnosis and treatment of intrathoracic UCD.

\section{Methods}

\section{Patients and study design}

Consecutive patients with intrathoracic UCD treated initially by VATs between January 2010 and June 2018 at the Department of Thoracic Surgery, Peking Union Medical Hospital (Beijing, China) were enrolled and retrospectively analyzed in this study. Eligible patients had pathologically confirmed $\mathrm{CD}$ disease with unknown cause intrathoracic mass requiring surgical exploration.

All patients were subjected to full history taking, collection of clinical manifestations, and laboratory investigations. Thoracic enhancement CT was done in all patients before surgery to record morphologic characteristics and enhancement characteristics of the tumor. Enhancement was defined as low, moderate, and high degree with a cutoff value of less than or equal to $30 \mathrm{HU}$, greater than $30 \mathrm{HU}$ but less than $60 \mathrm{HU}$, and greater than $60 \mathrm{HU}$, respectively. All the surgery was conducted by senior attending surgeon, and the pathological examination was confirmed by two experienced pathologists.

The study was approved by the Ethical Committee of Peking Union Medical Hospital, and patient consent was waivered by the local requirement. Written informed consent for image publication was obtained from the patient, and all patient data were anonymized in this study.

\section{Surgery procedure and follow-up}

Under general anesthesia, all procedures were performed under single-lung ventilation with double-lumen endotracheal intubation, which allows collapse of the lung on the operated side. Patients were placed in the lateral position. The trocar for the thoracoscope was positioned at the midaxillary line in the sixth or seventh intercostal space. Finger dissection was used in cases of adhesions of the lung to parietal pleura. Instruments for endoscopic surgery included a rigid thoracoscope, a camera, and reusable instruments. A 30-degree video thoracoscopic camera was inserted through the port. Other trocars were inserted under thoracoscopic visualization. Trocar number and placement varied according to the location of the mass. Most cases required one additional working port other than the camera port. Ports for the placement of operating instruments ranged from 5 to 12 $\mathrm{mm}$ in diameter. The dissections were performed using electrocoagulation instruments. Tumors were separated from adjacent organs using gentle blunt and sharp dissecting techniques. Hemostasis was conducted using electrocautery in areas distant from important organs such as vessels or nerves. To prevent tumor cells from spreading during operation, the removal of a dissected tumor was undertaken with extraction sacs. Working port incisions were extended to facilitate the extraction for large mass that was difficult to remove. The operations were completed by insertion of a chest suction tube for drainage through the initial port.

Surgical findings were recorded including the capsular integrity, the status of blood supply of the tumor, the relationship with other structures in the thoracic cavity, invasion to nearby structures, and whether the lesion was completely removed. R0 corresponds to resection for cure or complete remission without residual tumor, $\mathrm{R} 1$ to microscopic residual tumor, and R2 to macroscopic residual tumor.

Follow-up was conducted 1 month after surgery, and then every 6 months. Recurrence was defined as new soft tissue lesions in situ for patients with R0 resection, progression was defined as enlarged lesion when compared with preoperative CT findings for R2 patients, otherwise, it is defined as stable disease.

\section{Data}

The primary endpoint was surgical safety, and the secondary endpoint was long-term effect. The blood loss during surgery, the time of operation, postoperative hospital stays, total postoperative drainage, and surgical complications, and the improvement of patients' symptoms were recorded.

\section{Results}

\section{Patient characteristics}

A total of 10 patients including 7 women and 3 men, with a median age of 32 years (range: 15 to 66 years), were included in the study. Seven patients were detected incidentally by routine physical examination, and the remaining patients presented with chest pain, cough, sputum, and dysphagia. Postoperative pathology diagnosis showed that 8 patients had hyaline vascular $C D$ and others had plasma cell type. A typical case was showed in Fig. 1. All CT findings showed single-lesion mass with 6 located in the anterior mediastinum, and 4 in the middle and posterior mediastinum. The mean tumor size determined by CT was $4.66 \mathrm{~cm}$. Most cases $(n=9)$ had a mass with clear boundary including 3 tumor compressions of surrounding structures, while the remaining 1 


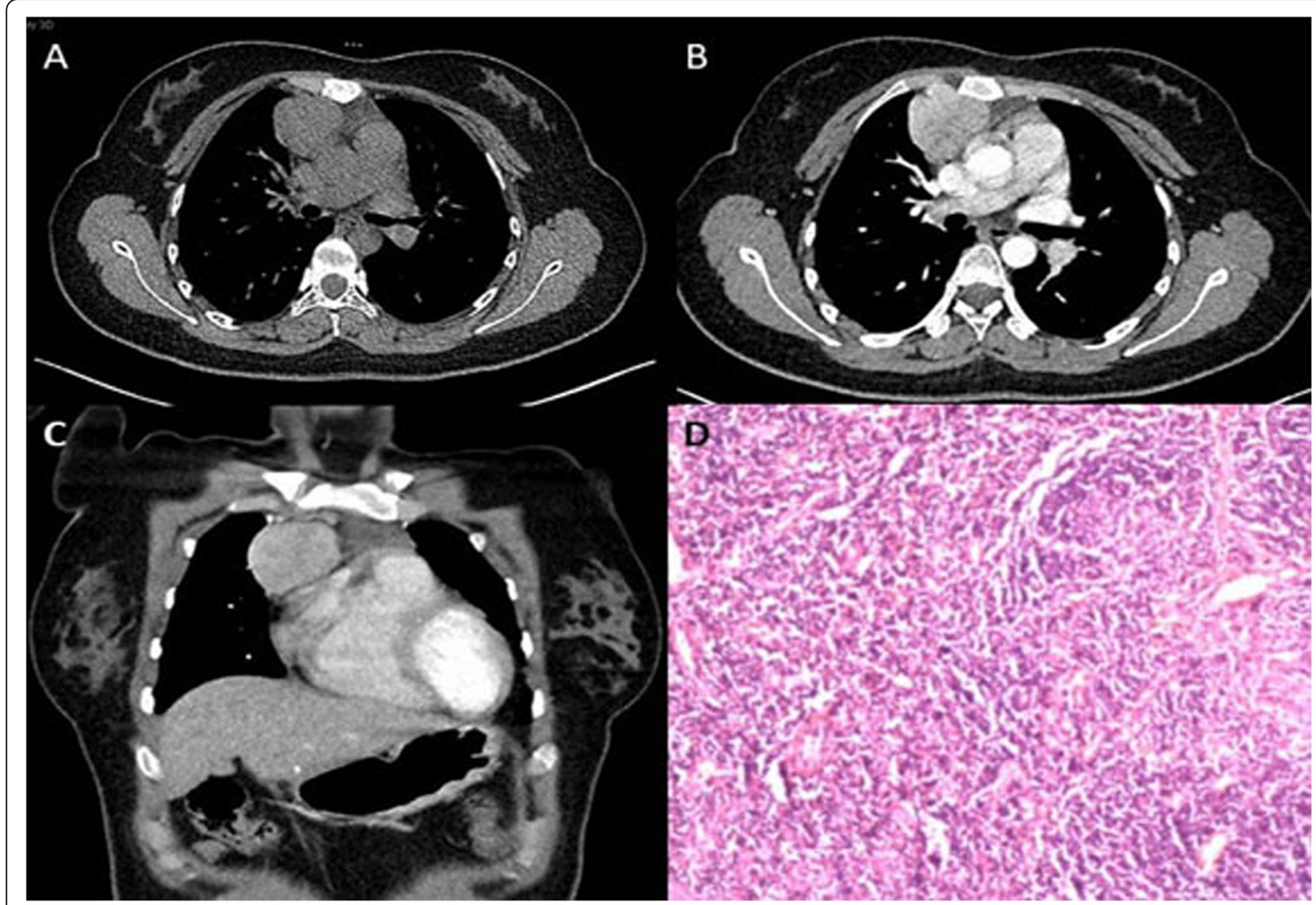

Fig. 1 A 21-year-old woman, she has no symptom and was admitted to our hospital because of a mediastinal mass found on a fortuitous CT scan. Contrasted chest CT showed a well-defined and homogeneous enhanced mass in the anterior mediastinum (a-c). The mass was whole resected by Video-assisted thoracoscopic surgery and confirmed hyaline vascular type Castleman disease. Histopathologic sections showed that capillary proliferation with perivascular hyalinization in the follicular and interfollicular, with a mixed inflammatory infiltrate of numerous small lymphocytes and plasma cells. (d, Hematoxylin and eosin, $\times 100)$. Chemotherapy was not suggested. She had been alive without recurrence for 5 years

showed tumor compression of surrounding esophageal and tracheal bronchus with unclear boundary. High and moderate degree enhancement was seen in 8 and 2 cases on contrast CT, respectively. Table 1 summarizes the clinical characteristics of the patients.

\section{Surgical findings}

All patients underwent VATs exploration with a median operation time of $125 \mathrm{~min}$ (90-265 min). The mean intraoperative bleeding was $118 \pm 88 \mathrm{ml}$. Most patients had capsuled mass $(n=9)$ with abundant blood vessels $(n=$ 6 ). Dense adhesion between the tumor and the posterior margin of the sternum was seen in 1 patient, while close relation between tumor and the right vagus nerve was seen in another patient. Most patients underwent a complete surgical resection by VATS, while one was converted to thoracotomy due to intraoperative injury of tracheal membrane, which lead to incomplete resection and macroscopic residual tumor. This patient underwent tracheal membrane repair via posterolateral thoracotomy using Prolene (Table 1).

\section{Treatment outcome}

These patients were discharged from the hospital $5 \pm 1$ days after the operations. The mean total postoperative thoracic drainage volume was $728 \pm 344 \mathrm{ml}$, and no patient had postoperative complications. By the data cutoff (April 2019), the median follow-up was 5 years (range: 1-9 years). Of the 9 patients following definitive surgical resection, all remain asymptomatic and free of disease at last follow-up. The patient treated with partial resection demonstrated a stable disease with a significant decrease in tumor size (Fig. 2). No patient received postoperative chemotherapy or radiotherapy as adjuvant therapy.

\section{Discussions}

This report reviewed the clinical characteristics, treatment, and outcomes of 10 patients with intrathoracic 
Table 1 Clinical characteristics of all patients in the study $(N=10)$

\begin{tabular}{|c|c|c|c|c|c|c|c|c|}
\hline $\mathrm{No}$ & Gender & $\begin{array}{l}\text { Age } \\
\text { (years) }\end{array}$ & $\begin{array}{l}\text { Disease } \\
\text { course } \\
\text { (months) }\end{array}$ & Symptoms & $\begin{array}{l}\text { Mass } \\
\text { size } \\
(\mathrm{cm})\end{array}$ & Chest contrast-enhanced CT characteritics & $\begin{array}{l}\text { Operative } \\
\text { approach }\end{array}$ & Operative findings \\
\hline 1 & female & 21 & 5 & None & 4.0 & $\begin{array}{l}\text { Well-defined mass with high-degree en- } \\
\text { hancement in right anterior mediastinum }\end{array}$ & $\begin{array}{l}\text { Right } \\
\text { VATs }\end{array}$ & $\begin{array}{l}\text { Complete capsule with abundant } \\
\text { vessels on the surface and tight } \\
\text { adhesion to posterior sternum }\end{array}$ \\
\hline 2 & female & 66 & 3 & $\begin{array}{l}\text { Chest } \\
\text { pain }\end{array}$ & 1.9 & $\begin{array}{l}\text { Well-defined mass with moderate degree } \\
\text { enhancement in right cardiophrenic angle }\end{array}$ & $\begin{array}{l}\text { Right } \\
\text { VATs }\end{array}$ & Mass with complete capsule \\
\hline 3 & male & 52 & 3 & None & 3.0 & $\begin{array}{l}\text { Locating in right paratracheal between the } \\
\text { azygous vein arch and SVC with } \\
\text { compression of SVC }\end{array}$ & $\begin{array}{l}\text { Right } \\
\text { VATs }\end{array}$ & $\begin{array}{l}\text { Complete capsule with clear boundary } \\
\text { with SVC }\end{array}$ \\
\hline 4 & female & 17 & 1 & None & 4.0 & $\begin{array}{l}\text { Well-defined mass with moderate degree } \\
\text { enhancement in right anterior } \\
\text { mediastinum }\end{array}$ & $\begin{array}{l}\text { Right } \\
\text { VATs }\end{array}$ & Mass with complete capsule \\
\hline 5 & male & 24 & 0.3 & None & 6.5 & $\begin{array}{l}\text { Well-defined mass with high-degree en- } \\
\text { hancement in right paratracheal between } \\
\text { the azygous vein arch and SVC }\end{array}$ & $\begin{array}{l}\text { Right } \\
\text { VATs }\end{array}$ & $\begin{array}{l}\text { Complete capsule with abundant } \\
\text { vessels on the surface }\end{array}$ \\
\hline 6 & female & 37 & 4 & Dysphagia & 6.4 & $\begin{array}{l}\text { Mass with high-degree enhancement } \\
\text { around the trachea and main bronchus } \\
\text { with compression of esophageal and tra- } \\
\text { cheal bronchus }\end{array}$ & $\begin{array}{l}\text { Right } \\
\text { VATs \# }\end{array}$ & $\begin{array}{l}\text { Incomplete capsule descending to the } \\
\text { carina and upward to the subclavian } \\
\text { artery with close connection to the } \\
\text { trachea }\end{array}$ \\
\hline 7 & male & 15 & 1 & $\begin{array}{l}\text { Cough, } \\
\text { sputum }\end{array}$ & 3.5 & $\begin{array}{l}\text { Mass with high-degree enhancement in } \\
\text { right anterior upper mediastinum with } \\
\text { compression tracheal and esophageal }\end{array}$ & $\begin{array}{l}\text { Right } \\
\text { VATs }\end{array}$ & $\begin{array}{l}\text { Complete capsule with abundant } \\
\text { vessels on the surface and tight } \\
\text { adhesion to vagus nerve }\end{array}$ \\
\hline 8 & female & 27 & 1 & None & 3.3 & $\begin{array}{l}\text { Well-defined mass with high-degree en- } \\
\text { hancement and calcification in left anterior } \\
\text { upper mediastinum }\end{array}$ & Left VATs & $\begin{array}{l}\text { Complete capsule with abundant } \\
\text { vessels on the surface }\end{array}$ \\
\hline 9 & female & 40 & 0.5 & None & 6 & $\begin{array}{l}\text { High-degree enhanced mass in left } \\
\text { posterior mediastinum, partially extending } \\
\text { into the intercostal space }\end{array}$ & Left VATs & $\begin{array}{l}\text { Complete capsule with abundant } \\
\text { vessels on the surface }\end{array}$ \\
\hline 10 & female & 40 & 0.3 & None & 6 & $\begin{array}{l}\text { Well-defined mass with high-degree en- } \\
\text { hancement in right anterior mediastinum }\end{array}$ & $\begin{array}{l}\text { Right } \\
\text { VATs }\end{array}$ & $\begin{array}{l}\text { Complete capsule with abundant } \\
\text { vessels on the surface }\end{array}$ \\
\hline
\end{tabular}

SVC superior vena cava; \# Right VATs converted to thoracotomy, the reason for the conversion to thoracotomy was intraoperative injury of the left main bronchus membrane

unicentric Castleman's disease, indicating that VATs is an acceptable procedure for the treatment and is associated with favorable outcome, fewer complications, and a decreased length of hospital stay. All patients were free of postoperative complications and discharged on schedule. With a five-year follow-up, complete resection of unicentric disease provided a recurrence-free survival for all patients, regardless of histologic subtype, and progression-free survival and decreased tumor size was seen for the patient treated with partial resection.

$\mathrm{CD}$ is a rare disease with an unknown cause and characterized by lymph node hyperplasia pathologically. Preoperative diagnosis of intrathoracic UCD is very difficult due to nonspecific clinical manifestations and imaging findings [18-20]. Therefore, the definitive diagnosis of UCD is established histologically by biopsy. Ultrasoundguided endoscopic fine needle aspiration and percutaneous transthoracic puncture biopsy are less invasive and easier to operate. However, aforementioned techniques are associated with potential damage to important structures such as large blood vessels or airways for biopsy in tumors located in the anterior mediastinum or mediastinum. In addition, specimens obtained with these techniques may not provide sufficient material for accurate diagnosis. VATs allows adequate exposure of thoracic cavity and the mass can be either sampled or totally removed, which provides a safe and effective diagnostic procedure for sampling of unicentric CD [16].

Ten patients with UCD treated by VATs in our center were summarized in the present study. Most of them are found by unintentional physical examinations, and a few had symptoms due to local compression by tumor. Nonspecific CT findings were seen in most patients, including moderate- to high-degree enhancement of the mass and unclear boundary with surrounding structure, which cannot be distinguished from other thoracic diseases, such as thymoma, lymphoma and malignance of the lung. Ultimately, definitive pathological diagnosis is required by using surgically resected specimen. Intraoperative blood loss was controllable without postoperative complications, indicating VATs is a safe and effective technique for UCDs diagnosis.

Surgical resection has been proven to be an ideal treatment for UCD [20-24]. A systematic review and meta- 


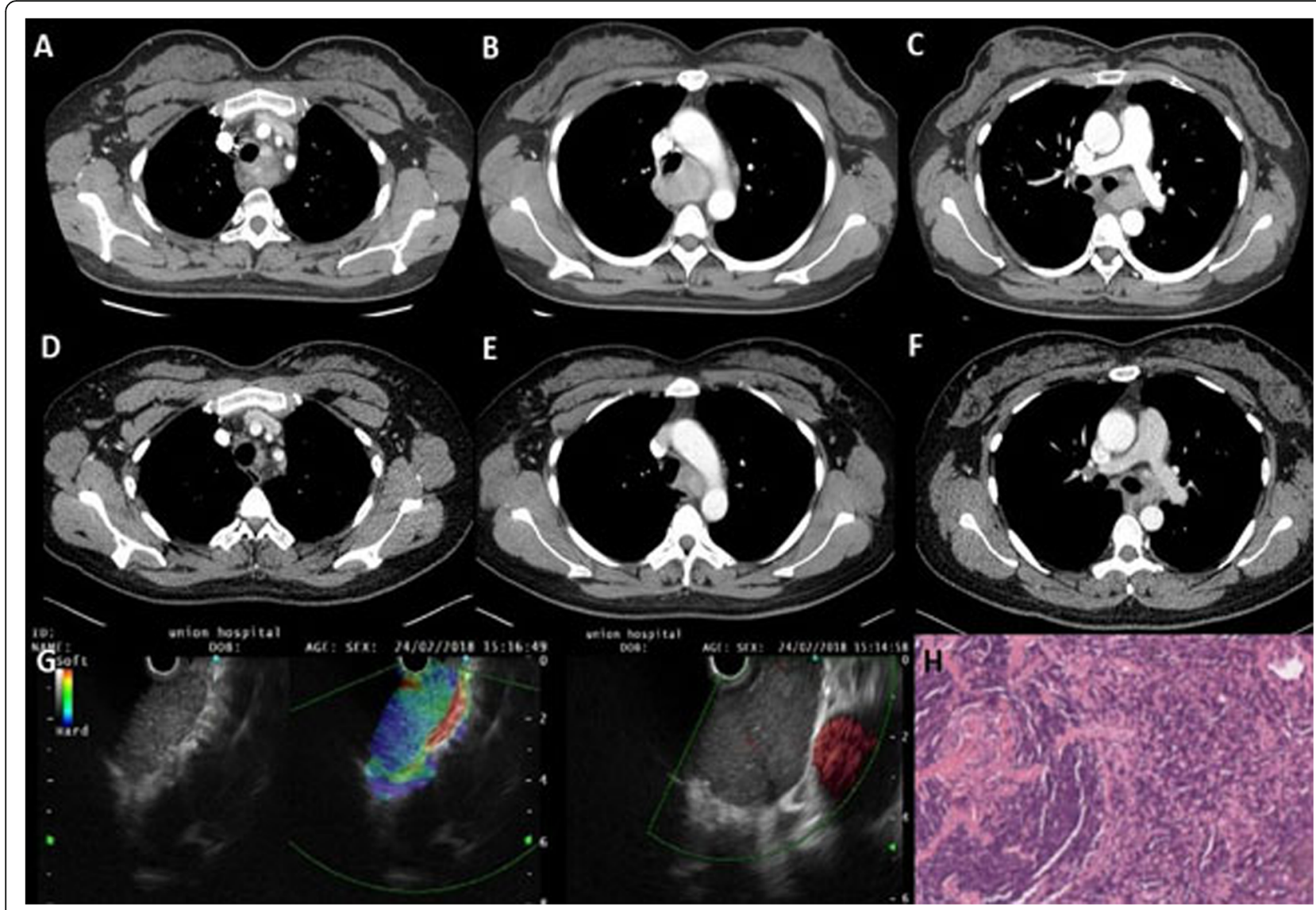

Fig. 2 A 37-year-old woman was was admitted to our hospital because of dysphagia for 3 months. Her chest CT showed Irregular soft tissue density, homogeneous enhanced, mass was seen between the trachea and the esophagus. The boundary was not clear, and the trachea, left main bronchus and esophagus were under pressure. a-c. Ultrasound gastroscopy showed a hypoechoic mass could be seen in the mediastinum of the esophagus from the incisors $22-26 \mathrm{~cm}$. A clear boundary, irregular edges were seen. The internal echo was still uniform, and no clear necrosis and calcification were seen. It could be seen that small blood vessels pass through the tumor, and the lesions are closely related to the pulmonary blood vessels by using Doppler. $\mathbf{g}$ This patient converse to thoracotomy because of intraoperative injury of the left main bronchus membrane, and the mass cannot be completely removed. Then she was diagnosed with Castleman disease of hyaline vascular variant in pathology. It was shown that the germinal centers typically form concentric rings, a phenomenon that is knownas "onion skinning".(H Hematoxylin and eosin, $\times 200$ ) After 1-year follow-up, chest CT showed no significant progression of the mass. During this period, the patient did not receive any adjuvant treatment (d-f)

analysis by Talat et al. summarized data of $404 \mathrm{CD}$ patients from 239 articles between 1954 and 2009 [25]. Of the 278 patients with UCD, 249 underwent surgery, 13 underwent resection combined with immunosuppressive therapy, and 16 received only immunosuppressive therapy. Only 13 patients died from disease-related causes after a ten-year follow-up. These findings demonstrated that surgical resection provide survival benefits in UCD patients and should be considered as the gold standard for treatment.

Open surgery is the traditional form for $\mathrm{CD}$ patients since CD lesions are hypervascular [26] and often adhere closely to surrounding tissues or important structures, which needs careful surgical approaching, especially in the mediastinum [27]. However, traditional thoracotomy is traumatic with an unclear visual field as well as prolonged time for operation and postoperative recovery. To date, a limited number of studies have reported the use of VATs for treating $\mathrm{CD}$, and the majority of them were case reports. Table 2 summarized the literatures that reported VATS-treated patients with unicentric Castleman's disease. In our study, patients' mass was about $5 \mathrm{~cm}$ in diameter with close relation to the surrounding structures. All were explored using VATs which was associated with controllable operation time, less blood loss during operation, shortened postoperative hospital stay. Nine patients achieved complete resection without recurrence after 5-yeay follow-up.

For mediastinal and posterior mass with unknown causes, especially for patients with compression symptoms of surrounding structures, such as dyspharyngia, thoracoscopy is only used as an exploration method, and 
Table 2 Video-assisted thoracoscopic surgery treatments and outcomes of patients with unicentric Castleman's disease in the literature

\begin{tabular}{|c|c|c|c|c|c|c|}
\hline $\begin{array}{l}\text { Reference } \\
\text { year }\end{array}$ & $\begin{array}{l}\text { Pathology } \\
\text { (sample } \\
\text { size) }\end{array}$ & Mass location & Intervention & $\begin{array}{l}\text { Surgical } \\
\text { margin }\end{array}$ & $\begin{array}{l}\text { Surgery } \\
\text { complication }\end{array}$ & $\begin{array}{l}\text { Outcomes } \\
\text { (follow-up } \\
\text { period) }\end{array}$ \\
\hline $\begin{array}{l}\text { Sarana B } \\
2017[28]\end{array}$ & $\mathrm{HV}(1)$ & right parahilar tumour & $\begin{array}{l}\text { Right VATs converted to thoracotomy }{ }^{a}+\text { three- }^{-} \\
\text {dimensional radiotherapy (cumulative radiation dose of } \\
44 \text { Gy) }\end{array}$ & R1 & No & $\begin{array}{l}\text { No } \\
\text { recurrence } \\
\text { (6-year) }\end{array}$ \\
\hline $\begin{array}{l}\text { Naomi A } \\
2015[29]\end{array}$ & $\mathrm{HV}(1)$ & paravertebral chest wall & Right VATs mass resection & RO & not report & not report \\
\hline $\begin{array}{l}\text { Suh JH } \\
2015[30]\end{array}$ & PC (1) & $\begin{array}{l}\text { right mid-superior medi- } \\
\text { astinum, between the } \\
\text { azygous and SVC }\end{array}$ & Right VATs mediastinal mass resection & RO & No & $\begin{array}{l}\text { No } \\
\text { recurrence } \\
\text { (5-year) }\end{array}$ \\
\hline $\begin{array}{l}\text { Rawashdeh } \\
\text { B } 2015 \text { [31] }\end{array}$ & $H V(1)$ & $\begin{array}{l}\text { central portion of left } \\
\text { upper lobe }\end{array}$ & $\begin{array}{l}\text { Left VATs left upper lobectomy and mediastinal } \\
\text { lymphadenectomy }\end{array}$ & RO & No & not report \\
\hline $\begin{array}{l}\text { Aoki M } \\
2014 \text { [32] }\end{array}$ & PC (1) & $\begin{array}{l}\text { anterior mediastinum } \\
\text { and extended to left } \\
\text { pleural cavity }\end{array}$ & $\begin{array}{l}\text { Left VATs, anterior mediastinal adipose tissue, thymus, } \\
\text { lesion and all swollen lymph nodes around it resection }\end{array}$ & RO & No & $\begin{array}{l}\text { No } \\
\text { recurrence } \\
\text { (5-year) }\end{array}$ \\
\hline $\begin{array}{l}\text { Ishikawa K } \\
2014 \text { [33] }\end{array}$ & $\mathrm{HV}(1)$ & $\begin{array}{l}\text { mid-mediastinum, } \\
\text { paratracheal between } \\
\text { SVC and trachea. }\end{array}$ & Right VATs mediastinal mass resection & RO & $\begin{array}{l}\text { myasthenic } \\
\text { crisis }\end{array}$ & $\begin{array}{l}\text { No } \\
\text { recurrence } \\
\text { (8-year) }\end{array}$ \\
\hline $\begin{array}{l}\text { Biçakçioğlu } \\
\text { P } 2014 \text { [34] }\end{array}$ & $\begin{array}{l}\text { HV (16) PC } \\
\text { (2) Mix (1) }\end{array}$ & not report & $\begin{array}{l}15 \text { thoracotomy and } 3 \text { VATs, } 1 \text { mediastinoscopy; biopsies } \\
\text { and mass excisions were performed in } 2 \text { and } 17 \text { cases. }\end{array}$ & RO & not report & not report \\
\hline $\begin{array}{l}\text { Amano Y } \\
2013[35]\end{array}$ & $H V(1)$ & $\begin{array}{l}\text { subcarinal } \\
\text { azygoesophageal recess }\end{array}$ & $\begin{array}{l}\text { Embolization of the feeding branches was performed } \\
\text { using a gelatin sponge and microcoils; Tumor resection } \\
\text { using VATS was performed on the day after the } \\
\text { embolization }\end{array}$ & RO & not report & $\begin{array}{l}\text { No } \\
\text { recurrence } \\
\text { (1-year) }\end{array}$ \\
\hline $\begin{array}{l}\text { Hideki O } \\
2013[36]\end{array}$ & $H V(1)$ & $\begin{array}{l}\text { right lower lobe around } \\
\text { the intermediate and } \\
\text { basal bronchi }\end{array}$ & Right VATs right middle-lower lobectomy & RO & No & $\begin{array}{l}\text { No } \\
\text { recurrence } \\
\text { (8-month) }\end{array}$ \\
\hline $\begin{array}{l}\text { Shohan S } \\
2011[4]\end{array}$ & $\mathrm{HV}(1)$ & $\begin{array}{l}\text { posterior mediastinal, } \\
\text { between azygous vein } \\
\text { and esophagus }\end{array}$ & Right VATs mediastinal mass resection & RO & No & not report \\
\hline $\begin{array}{l}\text { Ichiguchi O } \\
2009[5]\end{array}$ & $H V(1)$ & right cardiophrenic angle & Right VATs mediastinal mass resection & Ro & No & not report \\
\hline $\begin{array}{l}\text { Sakairi Y } \\
2009[37]\end{array}$ & $H V(2)$ & right lung hilum & $\begin{array}{l}1 \text { thoracoscopic biopsy, excised the right upper lobe, } \\
\text { containing the tumor; } 1 \text { EBUS-TBNA biopsy, excised right } \\
\text { middle lobe }\end{array}$ & Ro & No & $\begin{array}{l}\text { No } \\
\text { recurrence } \\
\text { (3/6-year) }\end{array}$ \\
\hline $\begin{array}{l}\text { Nishii T } \\
2004 \text { [15] }\end{array}$ & $H V(1)$ & $\begin{array}{l}\text { adjacent to the } \\
\text { pulmonary artery in the } \\
\text { right interlobar fissure }\end{array}$ & Right VATs mass resection & RO & No & not report \\
\hline $\begin{array}{l}\text { Ko SF } 2003 \\
{[21]}\end{array}$ & $\begin{array}{l}H V(6) P C \\
\text { (1) Mix (1) }\end{array}$ & pleura & $\begin{array}{l}4 \text { thoracotomies, } 2 \text { VATS2; } \\
2 \text { VATS converted to thoracotomy }{ }^{a}\end{array}$ & RO & No & $\begin{array}{l}\text { No } \\
\text { recurrence } \\
\text { (1-16-year) }\end{array}$ \\
\hline $\begin{array}{l}\text { Seirafi PA } \\
2003[16]\end{array}$ & $\mathrm{HV}(1)$ & $\begin{array}{l}\text { right paratracheal } \\
\text { between the azygous } \\
\text { and SVC }\end{array}$ & Right VATs mediastinal mass resection & RO & No & not report \\
\hline $\begin{array}{l}\text { lyoda A } \\
2003[9]\end{array}$ & $H V(1)$ & $\begin{array}{l}\text { right posterior } \\
\text { mediastinal, extended to } \\
\text { the tenth intercostal } \\
\text { space }\end{array}$ & Right VATs converted to thoracotomy ${ }^{a}$ & RO & No & $\begin{array}{l}\text { No } \\
\text { recurrence } \\
\text { (14-month) }\end{array}$ \\
\hline
\end{tabular}

HV hyaline vascular type Castleman disease, PC plasma cell type Castleman disease, VATs video-assisted thoracic surgery, SVC superior vena cava; ${ }^{2}$ The reason VATs converted to thoracotomy due to dense adhesions to the adjacent anatomical structures and diffuse bleeding.

should be actively converted to thoracotomy if thoracoscopic dissection is difficult. In our study, a case with an anterior mediastinal mass, which is usually well demarcated and closely related to the surrounding tissues, especially to vagus nerve, phrenic nerve, and superior vena cava, underwent complete resection by thoracoscopic blunt dissection. It should be noted that intraoperative hemostasis is needed to keep a good visual field during operation. Similar to previous findings by Sarana B [28], Ko SF [21], and Iyoda A et al. [9], we also reported a case with a mass tightly adhered to the trachea and the left pulmonary artery. Membrane of trachea was 
damaged during operation, and conversion to thoracotomy was required. After the intraoperative repair of the damaged tracheal membrane, the tumor could not be completely removed. The patient underwent chest enhancement CT at 1-year follow-up, and the tumor still existed. Despite failure to complete resection, significant reduction in tumor burden and improved symptoms of dysphagia was seen after surgery (Fig. 2). Therefore, together with published articles, our experience found that tight adhesion of mass to the surrounding structures and bleeding are the main causes of conversion from VATs to thoracotomy. In cases with bleeding risk or unclear relationship with surrounding tissues, VATs can be used for exploration, and timely conversion and repair are required to avoid serious consequences. In addition, our results also suggest that despite failure to completely removal of the mass, acceptable long-term efficacy and symptom improvement could be achieved by partial removal for patients with clinical symptoms.

This retrospective study had several limitations: first, we only enrolled cases accepted VATs, which could result in selection bias. Second, the sample size is small due to the rarity of $\mathrm{CD}$, and the follow-up time was shorter in some cases. The role of VATs needs to be evaluated in prospective studies with larger population and longer follow-up.

\section{Conclusions}

Our study demonstrated VATs is an alternative, minimally invasive technique for the diagnosis and treatment of UCD patients with thoracic mass. Complete resection was performed successfully in patients with welldemarcated masses. Incomplete resection can also achieve satisfying therapeutic effect when the mass was difficult to remove.

\section{Abbreviations}

CD: Castleman's disease; VATs: Video-assisted thoracoscopic surgery; UCD: Unicentric Castleman's disease; MCD: Multicentric Castleman's disease SVC: Superior vena cava

\section{Acknowledgements}

Not applicable.

\section{Authors' contributions}

Y W, collected the data, analysed the data. All authors interpreted the data and were involved in surgery. S L designed the methods for surgery. $Y$ W wrote the first draft of the manuscript, and F G provided critical revisions that were important for the intellectual content. All authors approved the final version of the manuscript.

\section{Funding}

This study was supported by National Key R\&D Program of China (No.2017YFC0907900/2017YFC0907903) which supported us in following up the patients.

\section{Availability of data and materials}

The datasets generated and/or analysed during the current study are not publicly available due to protecting individual patient privacy but are available from the corresponding author on reasonable request.

\section{Ethics approval and consent to participate}

This study was approved by the Ethical Committee of Peking Union Medical Hospital. Informed consent for the surgical procedures, obtained from all patients, was written.

\section{Consent for publication}

Written informed consent for publication of the participant clinical details was obtained from each patient. The patients and guardians of the participants that were minors at the time of the study $(<18)$ gave written consent for their respective children's personal or clinical details along with any identifying images to be published in this study.

\section{Competing interests}

The authors declare that they have no competing interests.

Received: 6 September 2019 Accepted: 1 June 2020

Published online: 10 June 2020

\section{References}

1. Castleman B, Towne WW. Case records of the Massachusetts General Hospital: case no. 40231. N Engl J Med. 1954;250(23):1001-5.

2. Castleman B, Iverson L, Menendez VP. Localized mediastinal lymphnode hyperplasia resembling thymoma. Cancer. 1956;9(4):822-30.

3. Keller AR, Hochholzer L, Castleman B. Hyaline-vascular and plasma-cell types of giant lymph node hyperplasia of the mediastinum and other locations. Cancer. 1972;29(3):670-83.

4. Shetty S, Brenes RA, Panait L, Sanchez JA. Video assisted thoracoscopic resection of a posterior mediastinal Castleman's tumor. J Cardiothorac Surg. 2011;6:113.

5. Ichiguchi O, Yoshioka M. Castleman's disease in the cardiophrenic angle resected thoracoscopically; report of a case. Kyobu Geka. 2009;62(2):161-3.

6. Kurai M, Kondo R, Kobayashi N, Hyogotani A, Yoshida K, Amano J. Castleman's disease arising from the chest wall. Jpn J Thorac Cardiovasc Surg. 2006;54(12):555-7.

7. Bonekamp D, Horton KM, Hruban RH, Fishman EK. Castleman disease: the great mimic. Radiographics. 2011;31(6):1793-807.

8. Herrada J, Cabanillas F, Rice L, Manning J, Pugh W. The clinical behavior of localized and multicentric Castleman disease. Ann Intern Med. 1998;128(8): 657-62.

9. Iyoda A, Yusa T, Hiroshima K, Fujisawa T, Ohwada H. Castleman's disease in the posterior mediastinum: report of a case. Surg Today. 2000;30(5):473-6.

10. Hountis P, Dedeilias P, Douzinas M. The management of Castleman's disease of the mediastinum: a case report. Cases J. 2008;1(1):330.

11. Kitami A, Suzuki T, Usuda R, Masuda M, Suzuki S. Diagnostic and therapeutic thoracoscopy for mediastinal disease. Ann Thorac Cardiovasc Surg. 2004; 10(1):14-8.

12. Ng CS, Yim AP. Technical advances in mediastinal surgery: videothoracoscopic approach to posterior mediastinal tumors. Thorac Surg Clin. 2010;20(2):297-309.

13. Demmy TL, Krasna MJ, Detterbeck FC, Kline GG, Kohman LJ, DeCamp MM Jr et al. Multicenter VATS experience with mediastinal tumors. Ann Thorac Surg. 1998;66(1):187-92.

14. Kita $Y$, Nogimura H, Ohi S, Kageyama $Y$, Matsushita $K$, Ito $Y$, et al. Thoracoscopically diagnosed multicentric Castleman disease; report of a case. Kyobu Geka. 2004:57(7):587-90.

15. Nishii T, Takei H, Maehara T, Kawamura S, Katuta Y. Castleman's disease in the interlobar fissure resected by video-assisted thoracoscopic surgery; report of a case. Kyobu Geka. 2004;57(10):990-2.

16. Seirafi PA, Ferguson E, Edwards FH. Thoracoscopic resection of Castleman disease: case report and review. Chest. 2003;123(1):280-2.

17. Sica GS, Di Lorenzo N, Sileri PP, Gaspari AL. Thoracoscopic approach to giant lymph node hyperplasia (Castleman's disease). Surg Laparosc Endosc Percutan Tech. 1999;9(4):282-5

18. Yamashita Y, Hirai T, Matsukawa T, Ogata I, Takahashi M. Radiological presentations of Castleman's disease. Comput Med Imaging Graph. 1993; 17(2):107-17.

19. Malara FA, Price D, Fabiny R. Mesenteric Castleman's disease: ultrasound, computed tomography and angiographic appearance. Australas Radiol. 2000;44(1):109-11. 
20. Luo JM, Li S, Huang H, Cao J, Xu K, Bi YL, et al. Clinical spectrum of intrathoracic Castleman disease: a retrospective analysis of 48 cases in a single Chinese hospital. BMC Pulm Med. 2015;15:34.

21. Ko SF, Ng SH, Hsieh MJ, Lin JW, Huang CC, Lee TY, et al. Castleman disease of the pleura: experience with eight surgically proven cases. Ann Thorac Surg. 2003;76(1):219-24.

22. Zhou N, Huang CW, Huang C, Liao W. The characterization and management of Castleman's disease. J Int Med Res. 2012;40(4):1580-8.

23. Ye B, Gao SG, Li W, Yang LH, Zhao SH, Ma K, et al. A retrospective study of unicentric and multicentric Castleman's disease: a report of 52 patients. Med Oncol. 2010;27(4):1171-8.

24. Chen CH, Liu HC, Tung KY, Lee JJ, Liu CL, Liu TP. Surgical outcome of superficial and deep Castleman disease. ANZ J Surg. 2007;77(5):339-43.

25. Talat N, Belgaumkar AP, Schulte KM. Surgery in Castleman's disease: a systematic review of 404 published cases. Ann Surg. 2012;255(4):677-84

26. Robert JH, Sgourdos G, Kritikos N, Didier D, Terraz S. Preoperative embolization of hypervascular Castleman's disease of the mediastinum. Cardiovasc Intervent Radiol. 2008;31(1):186-8.

27. Rena O, Casadio C, Maggi G. Castleman's disease: unusual intrathoracic localization. Eur J Cardiothorac Surg. 2001;19(4):519-21.

28. Sarana B, Jaal J, Tamm H, Laisaar T. Resection of unicentric interlobar Castleman disease with following adjuvant radiotherapy. SAGE Open Med Case Rep. 2017;5:2050313X17744481.

29. Naomi A, Kuroda H, Seto K, liduka S, Dejima H, Mizuno T, et al. Castleman's disease of the Chest Wall successfully resected by thoracoscopic SurgeryReport of a case. Kyobu Geka. 2015;68(13):1114-7.

30. Suh JH, Hong SH, Jeong SC, Park CB, Choi KB, Shin OR, et al. Anemia resolved by thoracoscopic resection of a mediastinal mass: a case report of unicentric Castleman's disease. J Thorac Dis. 2015;7(7):E189-93.

31. Rawashdeh B, Meyer M, Yimin D, Anthony C, Nguyn D, Moslemi M, et al. Unicentric Castleman's disease presenting as a pulmonary mass: a diagnostic dilemma. Am J Case Rep. 2015;16:259-61.

32. Aoki M, Otsuka T, Yanagi M, Yokomakura N, Nagata T, Nakamura Y, et al. A case of resected plasma cell type castleman's disease with intramediastinal lymph nodes spread. Ann Thorac Cardiovasc Surg. 2014;20(Suppl):682-5.

33. Ishikawa K, Kato T, Aragaki M, Ohbuchi T, Kimura S, Matsui Y, et al. A case of Castleman's disease with myasthenia gravis. Ann Thorac Cardiovasc Surg. 2014;20(Suppl):585-8.

34. Bicakcioglu P, Gulhan SS, Acar LN, Agackiran Y, Ozkara S, Kaya S, et al. Intrathoracic Castleman disease. Turk J Med Sci. 2014;44(2):197-202.

35. Amano Y, Takai D, Ohishi N, Shinozaki-Ushiku A, Fukayama M, Akahane M, et al. Successful treatment of mediastinal Unicentric Castleman's disease using video-assisted thoracoscopic surgery with preoperative embolization. Case Rep Med. 2013:2013:354507.

36. Ota H, Kawai H, Matsuo T. Unicentric Castleman's disease arising from an intrapulmonary lymph node. Case Rep Surg. 2013;2013:289089.

37. Sakairi Y, Shiba M, Kakizawa K, lida T, Katsumata M, Nakajima T, et al. Changes in diagnostic strategies for hilar-type Castleman's disease: report of two cases. Surg Today. 2009;39(12):1060-3.

\section{Publisher's Note}

Springer Nature remains neutral with regard to jurisdictional claims in published maps and institutional affiliations.

Ready to submit your research? Choose BMC and benefit from:

- fast, convenient online submission

- thorough peer review by experienced researchers in your field

- rapid publication on acceptance

- support for research data, including large and complex data types

- gold Open Access which fosters wider collaboration and increased citations

- maximum visibility for your research: over $100 \mathrm{M}$ website views per year

At $\mathrm{BMC}$, research is always in progress.

Learn more biomedcentral.com/submissions 